\title{
The genetic basis of murine and human sex determination: a review
}

\author{
KEN MCELREAVEY*, SANDRINE BARBAUX, ALEXANDRA ION \& MARC FELLOUS \\ Immunogénétique Humaine, Institut Pasteur, 25 rue du Dr Roux, 75724 Paris Cedex 15, France
}

\begin{abstract}
Determination of mammalian sex depends on the presence or absence of a functional testis. Testes are determined by the activity of the testis determining factor encoded by the sex determining gene, Y (SRY) located on the Y chromosome. Considerable evidence suggests that the $S R Y$ gene is the only gene on the Y chromosome that is both necessary and sufficient to initiate testis determination. Other steps in the mammalian sex determining pathway are unknown, although recent advances have shown that mutations in $\mathrm{X}$ chromosome and autosomal loci are also associated with sex reversal, suggesting the presence of at least one other sex determining gene. Duplications of sequences on the short arm of the human $\mathrm{X}$ chromosome, including the DAX-1 (DSS- $A \mathrm{HC}$ critical region on the $X$ chromosome, gene 1) gene, are occasionally associated with $X Y$ male-to-female sex reversal. In addition, mutations in the $S R Y$-related gene $S O X 9$ (SRY-related box) are associated with a failure of human testicular determination. Furthermore, the occurrence of inherited sex reversed conditions in both mice and men indicate the presence of at least one other sex determining gene. Breeding the $Y$ chromosome from certain Mus musculus domesticus strains into the laboratory mouse strain C57BL/6J results in XY male-to-female sex reversal. This suggests both allelic variation of the Sry gene and the presence of autosomal sex determining genes. In humans, familial cases of $S R Y$-negative XX males occur. Analysis of the transmission of the trait indicates the segregation of an autosomal or X-linked recessive mutation. The mutation may be in a gene whose wild-type function is to inhibit male sex determination. SRY may trigger male sex determination by repressing or functionally antagonizing the product of this gene.
\end{abstract}

Keywords: sex determination, sex differentiation, $S R Y$, sex reversal, XX male, XY female.

\section{Introduction}

In the early 1940s Alfred Jost and colleagues conducted a series of experiments which defined the fundamental concepts of mammalian sex determination and sex differentiation (Jost et al., 1973). Jost castrated foetal rabbits just before the onset of gonad differentiation. He observed that all embryos (XX and XY) had female internal genitalia with no development of the Wolffian ducts. He concluded that the testis produces substances that induce the development of Wolffian structures and also cause the regression of Müllerian ducts in a male foetus. These early experiments also indicated that the presence of an ovary was not necessary to induce Müllerian duct differentiation. Since removal of the undifferentiated mammalian foetal gonad results in the development of female internal and external

*Correspondence.

(C) 1995 The Genetical Society of Great Britain. genitalia, determination of sex is equated with testes determination. In humans, the testes produce all the hormones necessary for the complete development of the male phenotype; foetal Sertoli cells secrete anti-Müllerian hormone (AMH; also known as Müllerian inhibiting substance) which causes regression of the Müllerian ducts, and foetal Leydig cells produce testosterone which induces Wolffian duct development leading to the formation of epididymides, vasa deferentia and seminal vesicles. Dihydrotestosterone, derived from testosterone by the action of the enzyme $5 \alpha$-reductase, influences the external genitalia to develop into penis shaft, scrotum and glans penis.

Evidence that mammalian testis determination depends on the presence of a Y chromosome came from observations made in the late 1950 s and early 1960s when XO mice and XO humans were identified who did not develop testicular tissue (Ford $e t$ al., 1959; Russell et al., 1959; Cattanach, 1962). Sub- 
sequently XXY humans and XXY mice were discovered who developed as phenotypic males with testes, indicating that testis development was determined by the presence of the $\mathrm{Y}$ chromosome irrespective of the number of $\mathrm{X}$ chromosomes (Jacobs \& Strong, 1959; Cattanach, 1961). The factor encoded by a gene on the $\mathrm{Y}$ chromosome was termed the testis determining factor (TDF).

\section{The mammalian testis determining gene, $S R Y$}

\section{Evidence that SRY determines sex}

The identification and molecular analysis of human sex reversed conditions, $\mathrm{XY}$ females and $\mathrm{XX}$ males, were instrumental in the discovery of the testis determining gene. Three $46, \mathrm{XX}$ males and a $46, \mathrm{XX}$ true hermaphrodite were found who carried only $35 \mathrm{~kb}$ of Y-specific DNA in their genome (Palmer et al., 1989). A screen of the $35 \mathrm{~kb}$, testis determining region, for potential coding sequences by Goodfellow and colleagues (Sinclair et al., 1990) identified an open-reading frame (ORF) termed Sex Determining Region, $\mathrm{Y}$ gene ( $S R Y)$. The $S R Y$ gene fulfils many of the predicted properties of the testis determining gene, as follows.

1 Sequence analysis of the gene identified a motif of 79 amino acids which exhibits homology to the High Mobility Group proteins (HMG). This motif has DNA-binding properties suggesting a cell-autonomous function for the protein.

2 The gene is conserved on the $\mathrm{Y}$ chromosome in several other mammalian species.

3 The mouse Sry gene is located on the minimum portion of the $\mathrm{Y}$ chromosome known to be sex determining and is deleted from a mouse $\mathrm{Y}$ chromosome known to carry a mutant testis determining factor.

4 The expression pattern of $S r y$ is consistent with a role in testis determination as it is expressed for a short period (10.5-12 days post coitum) specifically in the somatic cells of the genital ridge. This is just before the first signs of testicular differentiation. Sry transcripts can also be detected in murine and human adult testis.

5 Genetic evidence to equate SRY as TDF came from the identification of XY females with mutations in the SRY-ORF (see discussion below).

6 Chromosomally female mice, who developed testes when a $14 \mathrm{~kb}$ fragment of DNA containing Sry was introduced as a transgene, demonstrate that Sry is both necessary and sufficient to determine testis formation (reviewed by Wolf et al., 1992).

\section{Properties of SRY: transcriptional activator or repressor?}

The human SRY gene consists of a single $850 \mathrm{bp}$ exon with the major transcription initiation site at $91 \mathrm{bp}$ upstream from the first methionine codon (the presumed translation initiation site). Other minor transcription initiation sites exist both $5^{\prime}$ and $3^{\prime}$ to this site (Vilain et al., 1992a; Behlke et al., 1993; Clépet et al., 1993; Su \& Lau, 1993). It is important to note that transcription initiation sites were identified in RNA isolated from adult testis or from cell lines following transfection with an $S R Y$-containing genome fragment. It is possible that other transcription initiation sites may be used in the developing foetal genital ridge. A $790 \mathrm{bp}$ CpG-rich island, within which is a potential recognition motif for the Wilms tumour gene product, WT1, is located $4.0 \mathrm{~kb}$ $5^{\prime}$ to the SRY-ORF (Call et al., 1990). Mutations in the WT1 gene have been described in patients with the Denys-Drash syndrome, a complex phenotype of nephropathy and complete or partial sex reversal in a 46,XY individual (Pelletier et al., 1991), suggesting that WT1 may directly or indirectly influence the process of sex determination.

The genomic organisation of the murine $S r y$ gene differs significantly from the human gene. The coding sequence, a single exon, lies within a $2.8 \mathrm{~kb}$ stretch of unique sequence that is flanked by a long inverted repeat of at least $15 \mathrm{~kb}$ (Capel et al., 1993). The HMG box domains of human SRY and murine Sry share 71 per cent identity but outside this region there is no significant homology. Sry transcripts in the murine foetal genital ridge are predominantly linear. However, in adult testis the Sry transcript is present as a circular RNA molecule. The transcript may arise from a stem-loop structure formed from a long primary RNA molecule that includes the inverted repeat. Although present in the cytoplasm, the circular transcript appears not to be associated with polysomes, hence it is unlikely to be translated. This indicates that Sry may have no function in adult testis. Human $S R Y$ transcripts can also be detected in adult testis although circular transcripts of the human $S R Y$ gene have not been found.

The SRY HMG box is both necessary and sufficient to bind DNA. However, little is known concerning possible target sequence(s) for SRY-binding although candidate motifs have been described. Like other proteins containing a single HMG box, SRY will bind to DNA in a sequence-specific manner, although there is a fairly high nonspecific binding affinity for linear DNA irrespective of the sequence 
(Nasrin et al., 1991; Harley et al., 1992, 1994). Human SRY appears to recognize the sequence AACAATG whereas murine Sry will bind with higher affinity to the sequence CATTGTT (Giese $e t$ al., 1992; Harley et al., 1994). Differences in DNAbinding affinity may reflect distinct differences in the interactions of the two proteins with DNA. This view is supported by in vitro studies which indicate that human SRY interacts with DNA primarily through minor groove contacts whereas murine Sry recognizes the major groove (Giese et al., 1994). Although SRY will bind to linear DNA with sequence specificity, it can also bind to four-way junctions (Ferrari et al., 1992). These are DNA structures that can be generated by recombination events and by intrastrand base pairing of inverted repeat sequences. The binding affinity of SRY for four-way junctions is similar to that observed in binding to linear DNA. SRY binding is independent of the sequence that makes up the junction (Ferrari et al., 1992).

The HMG domain of SRY/Sry not only has the ability to bind to DNA but also to induce DNAbending (Ferrari et al., 1992; Giese et al., 1992). Other HMG-domain proteins share this property (Giese et al., 1992). This may have a functional significance. For example, it might permit regulation of gene expression by juxtaposing distant sites in the DNA helix, thereby allowing interaction with other transcription factors, either directly between the SRY protein and other proteins, or indirectly by facilitating the construction of a scaffold structure.

Interaction between SRY and DNA either alone or with the aid of other proteins presumably regulates gene expression, either by activating or repressing gene transcription. Elegant in vitro studies by Dubin \& Ostrer (1994) indicate that mouse Sry has distinct DNA-binding and transcriptional activation domains. Transcriptional activation was observed when a murine $S r y$ construct was cotransfected into HeLa cells together with a reporter gene containing multiple copies of the AACAAT binding site. To map the activation domain, chimeric gene constructs consisting of the GALA DNA-binding domain and regions of the $S r y$ gene were cotransfected with a reporter gene containing the GALA DNA-binding site into chinese hamster ovary cells. In this system the GALA DNA-binding domain alone is unable to activate transcription when bound to its recognition site; it requires an activation domain. The activation function of mouse Sry was mapped to a glutamine/ histidine-rich domain in the $\mathrm{C}$ terminus of the ORF. This region has 53 per cent glutamine residues and 25 per cent histidine residues consisting of repeating units of $\mathrm{Q}_{5-13} \mathrm{FHDH}_{1-5}$. There is no corresponding region in human SRY. Similar constructs using the human $S R Y$ gene were unable to activate transcription in this system and instead specifically reduced transcription five-fold, suggesting that in contrast to murine Sry human SRY may have a repressor function.

\section{Relationship between SRY and pathologies of human sex determination}

Completely sex reversed individuals can be classified as either $46, \mathrm{XX}$ males or $46, \mathrm{XY}$ females. Incomplete or partial sex reversed syndromes are comprised of $46, X Y$ and $46, X X$ true hermaphrodites. About 1 in 20000 newborn males have a 46,XX karyotype and develop testes. $46, \mathrm{XX}$ true hermaphroditism is a much rarer disorder, clinically defined by the presence of both ovarian and testicular tissue present in the same individual. 46,XY gonadal dysgenesis is characterized by abnormalities of testis determination (reviewed by Berkovitz, 1992). This group can be further subdivided into $46, X Y$ complete (or pure) gonadal dysgenesis and 46,XY partial gonadal dysgenesis. 46, XY complete gonadal dysgenesis is characterized by completely female external genitalia and well-developed Müllerian structures. The gonad consists of a streak of fibrous tissue. As the name suggests $46, \mathrm{XY}$ partial gonadal dysgenesis is characterized by partial testis determination and a normal XY karyotype without mosaicism. Internal genitalia usually consist of a mixture of Wolffian and Müllerian ducts. Affected individuals exhibit varying degrees of masculinization of the external genitalia which broadly correlates with the extent of testicular differentiation.

Missense, nonsense and frameshift mutations have been described in SRY coding sequences of 46,XY females with complete gonadal dysgenesis (summarized in Fig. 1). These occur, with one exception, in the HMG DNA-binding motif of the gene (Berta et al., 1990; Jäger et al., 1990; Hawkins et al., 1992a,b; McElreavey et al., 1992; Affara et al., 1993). The exception is a point mutation generating a stop codon $3^{\prime}$ to the HMG box (Tajima et al., 1994). The frequency of mutations in the $S R Y$ gene in XY females with gonadal dysgenesis is low (approximately 15 per cent) which may be for several reasons. Some of these individuals may harbour mutations in other downstream sex determining genes (discussed below). In other cases sex reversal may be caused by mutations in sequences flanking the SRY gene. Two sex reversed subjects have been identified, one with $46, \mathrm{XY}$ complete gonadal dysge- 
(a)

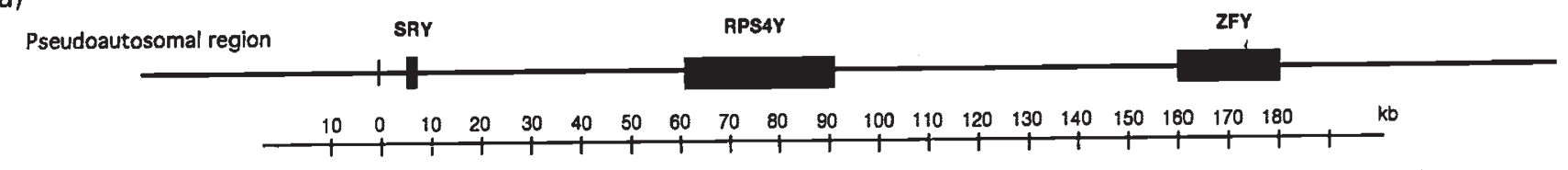

XY FEMALE NY

XY FEMALE SC

mIm

(b)

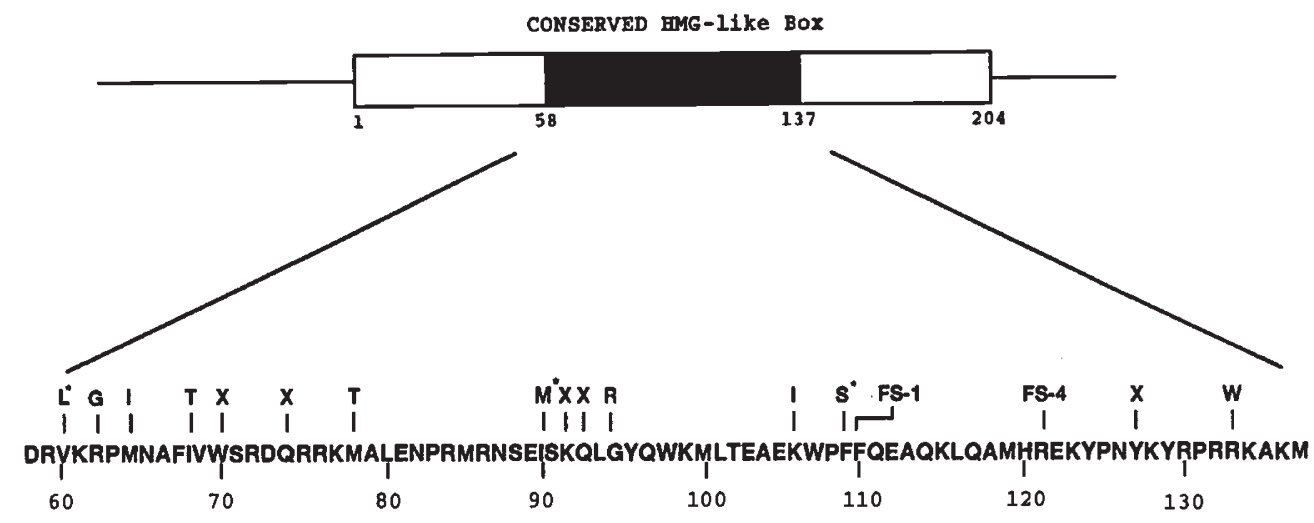

Fig. 1 Mutations in the human testis determining region associated with complete and partial forms of $46, X Y$ gonadal dysgenesis. (a) Schematic representation of the distal short arm of the Y chromosome is shown. Distances from the pseudoautosomal boundary are shown in kilobases. Genes identified in this region are indicated. Transcription of $S R Y$ proceeds from the centromere to the telomere. Black arms indicate Y-chromosomal material present in XY females with gonadal dysgenesis who harbour small interstitial deletions flanking the $S R Y$ gene. XY female NV has complete gonadal dysgenesis and has a de novo deletion which begins $0.8 \mathrm{~kb} 5^{\prime}$ to the $S R Y$ transcription initiation site and extends for a further $25-52 \mathrm{~kb}$. XY female SC has partial gonadal dysgenesis and harbours a de novo microdeletion of 4-7 kb $3^{\prime}$ to the $S R Y$ gene. (b) Mutations in the SRY HMG DNA-binding domain are indicated. Base-pair substitutions that are also carried by the father are indicated by an asterisk. FS indicates a frameshift. A point mutation has also been reported in the $3^{\prime}$ nonbox region generating a stop codon (Tajima et al., 1994).

nesis and the other with $46, \mathrm{XY}$ partial gonadal dysgenesis, who have microdeletions deleted $5^{\prime}$ and $3^{\prime}$ to the $S R Y$ gene, respectively (McElreavey et al., 1992, unpublished observations). These deletions may define regulatory elements. It is probable that some $46, X Y$ females who have a wild-type $S R Y$ coding sequence may harbour point mutations in sequence motifs essential for proper SRY expression. Finally, it cannot be excluded that some subjects may be wrongly diagnosed.

Sequence changes in the $S R Y$ gene do not always cause sex reversal. Three familial cases of $46, X Y$ sex reversal have been described where the affected individuals share the same amino acid change as their father (Hawkins et al., 1992b; Jäger et al., 1992; Vilain et al., 1992b). In each case a single base-pair change has resulted in an amino acid substitution in the HMG DNA-binding domain. The amino acid substitutions are Val60-Leu(V60L), Ile90-Met
(I90M) and Phe109-Ser(F109S). Each patient had $46, X Y$ complete gonadal dysgenesis. In the familial case with the sequence variant SRY ${ }^{\mathrm{V} 60 \mathrm{~L}}$ analysis of the streak gonad from affected XY females revealed only wavy ovarian-like tissue (Vilain et al., 1992b). Tubule-like structures were not observed, indicating a complete absence of SRY activity. Several hypotheses have been proposed to explain sex reversal in these families. It is possible that the sequence variants may be trivial polymorphisms not associated with the sex reversed phenotype. This hypothesis seems unlikely because polymorphisms in human $S R Y$ coding sequences have not been described. An alternative hypothesis is interaction between the variant SRY protein and another genetic determinant. A third hypothesis suggests that in vivo activity of the variant SRY protein is altered such that it is around a critical threshold level. 
Masculinization in a subject with a 46,XX karyotype may be caused by the presence of the $S R Y$ gene product. The incidence of the $S R Y$ gene in $46, \mathrm{XX}$ males and $46, \mathrm{XX}$ true hermaphrodites is indicated in Table 1. In general the presence of $S R Y$ in a 46,XX individual is associated with a more masculinized phenotype. Most 46,XX males without genital ambiguities harbour Y-chromosome material including the $S R Y$ gene. A minority of $46, \mathrm{XX}$ males with genital ambiguities carry $S R Y$ and a small proportion of XX true hermaphrodites are positive for $Y$ material. In rare cases a complete male phenotype without genital ambiguities can occur in the absence of $S R Y$.

Y-chromosome positive $\mathrm{XX}$ males and $\mathrm{XX}$ true hermaphrodites usually carry the $S R Y$ gene on the distal tip of the short arm of one of their X chromosomes. This results from an unequal exchange of material between the $\mathrm{X}$ and $\mathrm{Y}$ chromosomes during male meiosis. However, this by itself does not explain the spectrum of phenotypes observed in Ypositive $\mathrm{XX}$ individuals. In one pedigree, Abbas et al. (1993) described two XX subjects, one a true hermaphrodite with an essentially female phenotype and the other a male, who both carried the same amount of Y-specific DNA (35 kb) at position Xp22. As both sibs inherited the same Y-positive $\mathrm{X}$ chromosome, the phenotypic variability is most simply explained by inactivation of the $S R Y$-bearing $\mathrm{X}$ chromosome. The extent of testicular development would thus be dependent on the number of cells in the developing genital ridge having an active $S R Y$ bearing $\mathrm{X}$ chromosome.

\section{Inherited sex reversed conditions}

\section{Inherited sex reversal in mice: the Tda loci}

When the $\mathrm{Y}$ chromosome of certain wild populations of Mus musculus domesticus is backcrossed into the C57BL/J6 (B6) mouse genome (a highly inbred laboratory strain), a proportion of the $X Y$ offspring develop as $X Y$ females and $X Y$ true hermaphrodites. Eicher et al. (1982) first described XY murine sex reversal when the $M . m$. domesticus $\mathrm{Y}^{\mathrm{POS}}$

Table 1 Presence or absence of SRY in 46,XX males and $46, \mathrm{XX}$ true hermaphrodites

\begin{tabular}{lcc}
\hline & SRY present & SRY absent \\
\hline XX male without ambiguities & 36 & 3 \\
XX male with ambiguities & 4 & 39 \\
XX true hermaphrodite & 6 & 32 \\
\hline
\end{tabular}

chromosome (POS is derived from Val Poschiavo, Switzerland, the geographical origin of the $Y$ chromosome) was placed into the B6 genome. After backcrossing to $\mathrm{B} 6$ females for several generations the sex ratio was skewed in favour of females. However, the ratio of $\mathrm{XY}$ to $\mathrm{XX}$ foetuses remained constant at 1:1. Further examination revealed that some females had an XY chromosome constitution. Other $\mathrm{XY}$ foetuses developed into hermaphrodites while the 'normal' males had small testes and reduced fertility. From this observation, Eicher and colleagues proposed that the testis-determining gene on the $\mathrm{Y}$ chromosome of $M . m$. domesticus (Tdy ${ }^{\mathrm{POS}}$ ) interacts improperly with a putative $\mathrm{B} 6$ recessive, testis determining autosomal gene $(T d a)$. Thus there are two aspects of this form of XY sex reversal, the Y-linked $T d y^{\mathrm{POS}}$ and an autosomal locus Tda. Mice that possess $T d y^{\mathrm{POS}}$ and are homozygous for $T d a$ develop as either hermaphrodites or as XY females. Other $M$. domesticus $\mathrm{Y}$ chromosomes have been identified that cause sex reversal when transferred to the $\mathrm{B} 6$ background including $\mathrm{Y}^{\mathrm{DOM}}$ which was derived from mice originally isolated from Tirano in Italy.

With the identification of the $S r y$ gene, the cause of the Y-linked aspect of sex reversal has been the subject of recent studies. The simplest explanation for the sex reversal is a difference between $S r y$ alleles. To investigate this hypothesis, Lau and colleagues (Coward et al., 1994) sequenced the Sry$\mathrm{ORF}$ and flanking sequences from $\mathrm{Y}^{\mathrm{DOM}}$ and other $\mathrm{Y}$ strains and compared it to the $S r y$ sequence cloned from the mouse strain 129 (the Y chromosome is of molossinus origin in this strain) published by Gubbay et al. (1990). Sequence comparison predicts several structural differences between the $\mathrm{Y}^{\mathrm{DOM}}$ and 129.Y Sry proteins. Within the ORF there are five single-base changes, each causing amino acid substitutions. In addition, a pair of codons for glutamine are deleted and a pair of codons for a histidine and a glutamine are deleted. Perhaps the most significant change is the presence of a functional termination codon in the Sry ${ }^{D O M}$ which effectively truncates the molecule by one half (predicted MW of $28.4 \mathrm{kDa}$ compared to $49.5 \mathrm{kDa}$ ). However, in vitro translation of other Sry alleles from other domesticus strains indicated the presence of this stop codon, effectively excluding it as the Ylinked aspect of B6 sex reversal. Further comparison of the Sry-ORF between Y chromosomes of different origins revealed a single polymorphic site consisting of a stretch of in-frame glutamine codons (CAG), $3^{\prime}$ to the HMG box. Sry clones from laboratory strains FVB/N, SJL/J and SWR/J contain 12 
CAG repeats, whereas clones from $\mathrm{Y}^{\mathrm{DOM}}$ and $\mathrm{Y}^{\mathrm{POS}}$ contain 11 sites and $\mathrm{Y}^{\mathrm{AKR}}$ contains 13 repeats. Introduction of the $\mathrm{Y}^{\mathrm{AKR}}$ chromosome onto the B6 genetic background results in testicular dysgenesis but not true sex reversal (i.e. ovarian tissue does not develop). The number of glutamine repeats at this site may be responsible for sex reversal in the B6 background. However, as noted by Eicher (1994) in the absence of functional data, the change in glutamine repeats may be a simple polymorphism unassociated with sex reversal. An alternative explanation of $\mathrm{B} 6 \mathrm{Y}^{\mathrm{POS}}$ sex reversal proposed that the Y-linked aspect of sex reversal may result from mutation in regulatory elements outside the SryORF which affect timing of Sry expression. This hypothesis is supported by data presented by Palmer \& Burgoyne (1991) who demonstrated that an XY foetus with a $\mathrm{Y}^{\mathrm{PO}}$ chromosome developed testis cords $14 \mathrm{~h}$ later than an XYB6 foetus, whereas limb development (taken as a measure of overall development) was unaffected by the strain of $Y$ chromosome. These data also suggest that the autosomal component of $\mathrm{YY}^{\mathrm{POS}}$ sex reversal, the postulated testis determining locus $T d a-1$, need not be a testis determining gene but rather may be an early acting ovarian determining gene. B6 is a fast-developing strain, and the $\mathrm{Y}^{\mathrm{POS}}$ testis determining gene may not act early enough to divert gonadal development away from the default ovarian pathway. The role of the autosomal component of $\mathrm{B} 6 \mathrm{Y}^{\mathrm{POS}}$ sex reversal in testis (or ovarian) determination will be aided by the mapping and identification of the Tda loci (Eicher $e t$ al., 1995).

\section{$T$-associated sex reversal (Tas)}

A locus on chromosome 17 of the mouse which segregates with the brachyury alleles hairpin tail $\left(T^{h p}\right)$ or T-Orleans $\left(T^{O r l}\right)$ is necessary for normal testis development. This locus, termed T-associated sex reversal (Tas), is located in a deletion of the $T$ locus that is common to both $T^{h p}$ and $T^{O r l}$ alleles. Abnormal testis development occurs in B6 $T^{\text {Orll+ }}$ or $T^{h p /+}$ mice provided that the $\mathrm{Y}$ chromosome is derived from the AKR/J strain (Washburn \& Eicher, 1989). B6 mice carrying a B6 Y chromosome have normal testis development. This indicates that failure of testis development is a result of an abnormal interaction between an Sry and a Tas allele.

\section{Human familial $X X$ and $X Y$ seX reversal}

Most cases of 46,XY gonadal dysgenesis are sporadic. However, several familial cases have been described of which six have an apparent X-linked recessive (or sex-limited autosomal dominant) mode of transmission (Sternberg et al., 1968; Espiner et al., 1970; German et al., 1978; Bernstein et al., 1980; Mann et al., 1983; Fechner et al., 1993). In one of these families, affected $46, \mathrm{XY}$ subjects carried a duplication of distal $\mathrm{Xp}$ sequences, and presented with other congenital abnormalities (Bernstein et al., 1980). A search for duplicated Xp sequences was also performed in the family reported by Berkovitz and colleagues, using Southern blotting; however, they did not detect duplication of $\mathrm{Xp}$ sequences (Fechner et al., 1993).

Familial cases of XX sex reversal have also been described and in some of these pedigrees it has been shown that $S R Y$ is absent (reviewed by de la Chapelle, 1987). In at least two familial cases the parents were first cousins which suggests the transmission of a recessive allele responsible for the trait (McElreavey et al., 1993). Recessive inheritance is also suggested by the family described by Kuhnle et al. (1993), where two cousins were described, a $46, \mathrm{XX}$ male and a $46, \mathrm{XX}$ true hermaphrodite. The $S R Y$ gene was not detected in either individual. In each family, homozygosity of a recessive autosomal or X-linked gene may be responsible for XX sex reversal, although in one pedigree the fathers of two XX males were found to be paternal first cousins which effectively excludes $\mathrm{X}$ chromosome inheritance of the trait in this family (de la Chapelle, 1981). These families are too small to perform conventional linkage analysis; however, with recent advances in gene mapping techniques such as homozygosity mapping (Lander \& Botstein, 1987; Kruglyak et al., 1995) it may be possible to identify the genes responsible.

\section{Autosomal and $X$ chromosome loci associated with sex reversal}

\section{$X p$ duplications and sex reversal}

Partial duplications of the short arm of the $X$ chromosome have been described in $15 \mathrm{XY}$ subjects with ambiguous or female external genitalia (Narahara et al., 1979; Nielson \& Langkjaer, 1982; Scherer et al., 1989; Stern et al., 1990; May et al., 1991; Ogata et al., 1992; Bardoni et al., 1993, 1994; Arn et al., 1994; Rao et al., 1994). Where examined, the $S R Y$ gene was apparently intact. In five cases histological examination of gonads revealed gonadal dysgenesis. The phenotype of these patients was variable with some subjects presenting with severe 
psychomotor retardation and facial dysmorphy as well as abnormal genital development, and others with only $46, \mathrm{XY}$ gonadal dysgenesis.

By what mechanism is testis determination impaired by a duplication of a portion of the $\mathrm{X}$ chromosome? Duplications of $\mathrm{Xp}$ leading to sex reversal in an $X Y$ individual contrasts with $47, \mathrm{XXY}$ and $48, \mathrm{XXXY}$ individuals who, in spite of the presence of more than one copy of $X p$, develop a male phenotype. To explain why XY individuals with $\mathrm{Xp}$ duplications are sex reversed and individuals with supernumary $\mathrm{X}$ chromosomes and a single $\mathrm{Y}$ are not, Ogata and colleagues (Ogata et al., 1992) proposed that sex reversal is caused by a double dosage of an X-linked gene(s) which is normally subject to $\mathrm{X}$-inactivation. Thus $\mathrm{XY} \mathrm{Xp}+$ subjects have two active copies of the gene and are sex reversed, whereas XXY subjects have one active and one inactive $\mathrm{X}$ chromosome.

Considerable effort has recently been directed towards identifying the gene responsible for $\mathrm{Xp}+$ sex reversal. An analysis of 27 individuals with a female phenotype and an XY karyotype by Camerino and colleagues (Bardoni et al., 1994) identified a single individual who carried a microduplication distal to the $D M D$ locus at $\mathrm{Xp} 21.3$. The dosage sensitive sex reversal (DSS) region was defined by determining the extent of overlap of the microduplication with the other cytogenitically detected duplications. A common region of $160 \mathrm{~kb}$ was delimited which defines the DSS critical interval. The locus for $\mathrm{X}$-linked adrenal hypoplasia congenita (AHC) and hypogonadotrophic hypogonadism (HHG) also maps to this region. It is possible that the $D S S$ and $A H C$ genes are identical and duplications interfere with normal testes development, while loss-of-function mutations result in abnormal adrenal development. Recently a gene termed $D A X-1$ ( $D S S-A H C$ critical region on the $X$, gene 1 ) was identified within the $160 \mathrm{~kb}$ region (Zanaria et al., 1994). DAX-1 encodes a new member of the nuclear hormone receptor superfamily, containing a novel DNA-binding domain and ligand-binding domain. Missense mutations in $D A X-1$ coding sequences have been identified in patients with AHC and HHG. Does the $D A X-1$ gene correspond to the DSS gene? One of the predicted properties of the gene responsible for DSS sex reversal is that it is subject to $X$-inactivation. The $\mathrm{X}$-inactivation status of the $D A X-1$ gene is not yet known. Further analysis of $\mathrm{XY}$ females for microduplications of the DSS region and the construction of transgenic mice with multiple copies of $D A X-1$ may provide an answer to this question.

\section{SRY-related genes and sex reversal}

The term SOX has been used to describe a family of genes that share greater than 60 per cent homology with the $S R Y$ HMG-box region (SRY-related HMGbox genes; Denny et al., 1992). Several murine members of this family are expressed during development (Wright et al., 1993). Mutations in the human homologue of one of these genes, $S O X 9$, can cause campomelic dysplasia (CD) and 46,XY sex reversal. Campomelic dysplasia is predominantly a skeletal malformation syndrome. Characteristic features include congenital bowing of the long bones, together with brachydactyly, clinodactyly, and micrognathia. The majority of XY patients with $\mathrm{CD}$ are sex reversed females (Cooke et al., 1985). Goodfellow and colleagues cloned a translocation breakpoint in one patient $(46, X Y, t(2 ; 17)(q 35 ; \mathrm{q} 23-24))$ and isolated an $S R Y$-related gene termed $S O X 9$ adjacent to the translocation breakpoint (Foster et al., 1994). Mutations in the SOX9 gene were found in six campomelic dysplasia patients, three of which were $46, X Y$ females. Several of these mutations are predicted to abolish gene function. This establishes that sex reversal and CD are caused by mutations in a single gene, $S O X 9$. In all cases only a single allele was mutated suggesting that haploinsufficiency of $S O X 9$ is the probable cause of the phenotype. Why should a mutation in a single gene result in a failure of testicular formation and abnormal bone development? As noted by Goodfellow and colleagues mesenchymal cells may provide the link (Foster et al., 1994). Mesenchymal cells migrate from the mesonephros and are necessary for testis formation. Mesenchymal cells also give rise to bone and cartilage forming cells. It is possible that $S O X 9$ expression may be necessary for proper mesenchymal cell function.

\section{SF-1 and $A M H$}

$\mathrm{AMH}$ is the first substance known to be secreted by foetal Sertoli cells. Production of AMH in the male foetus causes regression of the Müllerian ducts; however, the role of $\mathrm{AMH}$ in the adult ovary is unclear. Purified AMH induces the formation of seminiferous cord-like structures in foetal rat ovaries in vitro (Vigier et al., 1987), suggesting that $\mathrm{AMH}$ may have two roles: to repress formation of female genitalia and influence testicular formation. Transgenic mice chronically expressing $A M H$ (Behringer et al., 1990) exhibit a range of sexual ambiguities, which also suggests that AMH may well have pleio- 
tropic effects. Because of its biological activities in the developing foetal gonad, $A M H$ has been considered a candidate target gene for SRY in the testis determining pathway. However, several observations suggest that this is not the case. The expression profiles of both molecules differ, $A M H$ transcripts can be detected by in situ hybridization in murine Sertoli cells at about 12 d.p.c. and expression can be detected in Sertoli cells until after birth (Munsterberg \& Lovell-Badge, 1991). Sry expression can be detected $20 \mathrm{~h}$ prior to the appearance of $A M H$ transcripts. Genetic data indicate that there are probably one or more steps between SRY and AMH in the sex determination/differentiation pathway. Certain individuals have been identified with defective regression of the Müllerian ducts (Persistent Müllerian Duct Syndrome (PMDS)). They have an XY karyotype with normal male external genitalia, though they often present with undescended testes. Their internal genitalia are feminine (bilateral fallopian tubes, uterus and an upper vagina). Some of these individuals carry mutations in the $A M H$ gene (Imbeaud et al., 1994). The $A M H$ mutant phenotype (male pseudohermaphrodite with testes) contrasts with that of $\mathrm{XY}$ females with gonadal dysgenesis who have a wild-type $S R Y$ gene. Cotransfection of SRY expression plasmids and AMH reporter constructs into a cell line derived from the differentiating gonadal ridge of male rat embryos also indicates that SRY can induce AMH expression by an indirect manner, because the SRY protein did not bind to $A M H$ regulatory elements (Haqq et al., 1994). This suggests that other factors must intervene to modulate $\mathrm{AMH}$ expression. One of these may be Steroidogenic factor 1 .

Steroidogenic factor 1 (SF1) has been identified as a transcriptional regulatory protein necessary for the expression of cytochrome P450 steroid hydroxylases in murine adrenocortical cells (Lala et al., 1992). The cytochrome P450 steroid hydroxylases convert cholesterol to various steroid products. Murine SF1 closely resembles an orphan nuclear receptor isolated from Drosophila, designated fushi tarazu factor 1 or FTZ-F1 (Lavorgna et al., 1991). In Drosophila the FTZ-F1 protein functions as a positive regulator of transcription of the $f t z$ gene, a zygotic segmentation gene. The predicted structure of the $\mathrm{SF} 1$ protein is similar to DAX-1. It is also a member of the nuclear hormone receptor superfamily and has distinct ligand-binding and DNA-binding domains. $S F-1$ and another cDNA designated embryonal long terminal repeat-binding protein $(E L P)$ arise from the same structural gene by the use of alternative promoters and splicing.
Expression of SF1 can be detected in gonad tissues (Lynch et al., 1993). Rat SF1 transcripts can be detected in ovarian tissue and in a rat Leydig tumour cell line. SF-1 is necessary for the expression of P450 aromatase, an enzyme that catalyses the conversion of androgens to oestrogens and which is expressed primarily in the adult ovary. In adult mice, SF1 transcripts can be detected in all primary steroidogenic tissues (adrenal cortex, testicular Leydig cells, Sertoli cells and theca cells of the ovary) (Ikeda et al., 1993, 1995). Evidence that SF-1 may play a role in gonad development and perhaps directly in sex determination is suggested by three lines of evidence. First, SF1 transcripts can be detected in the urogenital ridge as early as embryonic day 9-9.5. Expression can also be detected in foetal Sertoli cells. Secondly, SF1 appears to regulate directly the expression of AMH (see below) and thirdly, targeted disruption of the Ftz-F1 gene to produce mice homozygously deficient in both isoforms, SF-1 and ELP, generated animals which lacked adrenal glands and gonads and died by postnatal day 8, probably from adrenocortical deficiency (Luo et al., 1994).

What is the relationship between SF-1 and AMH? Expression of the mouse $A M H$ gene in transfected Sertoli cells requires a conserved CCAAGGTCA element which matches exactly the recognition sequence of the nuclear receptor SF-1 (Shen et al., 1994). This element is bound by a single Sertoli cell nuclear protein that is recognized by a specific antiSF-1 antibody. $S F-1$ and $A M H$ are co-expressed in Sertoli cells during embryonic development. Both $S F-1$ and $A M H$ transcripts can be detected in the male in the period just following testis formation, during Müllerian duct regression. In contrast, in the female gonad the level of SF-1 transcripts sharply declines during this period (Shen et al., 1994). These observations imply that SF-1 is a major positive regulator of $A M H$ gene expression during the period of Müllerian duct regression. However, other factors may be required, because cotransfection data reported by Haqq et al. (1994) suggests that SF-1 might repress the synthesis of AMH.

\section{A genetic model of mammalian sex determination}

\section{$S R Y$ represses a negative regulator of testis formation}

Familial cases of SRY-negative XX sex reversal suggest the transmission of a recessive mutation which in a homozygous state in an XX individual is suffi- 
cient to cause sex reversal. A recessive mode of inheritance of XX sex reversal has also been described in several domestic animals. Goats with the autosomal dominant polled $(P)$ mutation are hornless. Chromosomal females (XX) homozygous for the polled mutation, $P / P$ develop testicular tissue. Affected animals do not carry the SRY gene (Pailhoux et al., 1994). Inherited XX sex reversal has also been described in the American cocker spaniel dog; again the transmission of the trait is compatible with a recessive mode of inheritance.

It is simplest to interpret familial cases of $\mathrm{XX}$ seX reversal in terms of a single autosomal or X-linked locus $Z$, whose mutant recessive allele $\left(Z^{-}\right)$confers a male phenotype (McElreavey et al., 1993). XX individuals who are $Z^{-} / Z^{-}$homozygotes will express a male phenotype. Therefore XX sex reversal can be regarded as a loss-of-function at the $Z$ locus rather than a gain-of-function mutation in the testis determining pathway. The function of $\mathrm{Z}$ may be to act as an inhibitor of male-specific genes. The wild-type function of SRY may be to repress or otherwise negatively regulate the activity of $\mathrm{Z}$. As SRY is known to have a DNA binding capacity it may function by repressing the synthesis of $\mathrm{Z}$ (Fig. 2). This model proposes that a positive regulator, SRY, might function mechanistically by inhibiting an inhibitor.
Fig. 2 (a) A regulatory cascade hypothesis for mammalian sex determination. SRY inhibits a negative regulator of male development. Normal and sex reversed conditions are indicated. ON and OFF represent the activity state of malespecific genes. (1) In wild-type males, SRY protein is present and antagonizes $Z$ activity (as drawn) or inhibits $Z$ by acting as a repressor of $Z$ synthesis (not drawn). In the absence of $Z$ activity, male-specific genes are $\mathrm{ON}$ and a male phenotype develops. (2) In wild-type XX females SRY is absent; as a consequence $\mathrm{Z}$ is active and inhibits male-specific genes. Female differentiation thus occurs. (3) XX sex reversed patients who lack SRY and yet develop a male phenotype are proposed to be defective in the $Z$ gene (homozygous for a $Z^{-}$mutation). In the absence of functional $\mathrm{Z}$ activity, malespecific genes are not inhibited and male development occurs in an XX background. (4) XY sex-reversed females with a wild-type $S R Y$ gene are predicted to harbour a mutation at the $Z$ locus $\left(Z^{\mathrm{i}}\right)$ which renders them insensitive to the inhibitory effect of SRY. Consequently $Z$ protein inhibits male sex determination, permitting female sex differentation. (b) Schematic representation of interaction between SRY and the DSS gene located at Xp21.3. (1) In XY individuals deleted for DSS there is no inhibition of malespecific genes; male-specific genes are $\mathrm{ON}$ and a male phenotype develops. (2) When the DSS gene is present in two active copies as described in some $\mathrm{XY}$ females, SRY is unable to repress completely the synthesis of DSS or inhibit DSS activity. As a consequence, male-specific genes are inhibited and a female phenotype develops. (a)
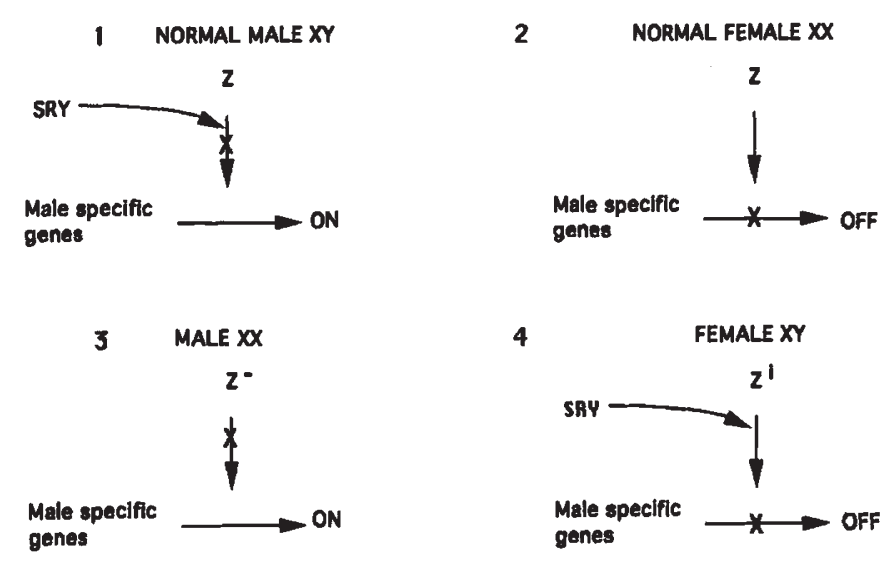

(b)

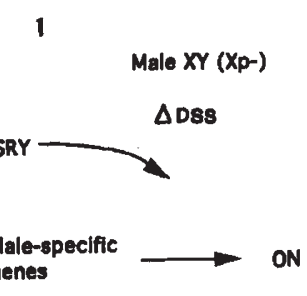

2

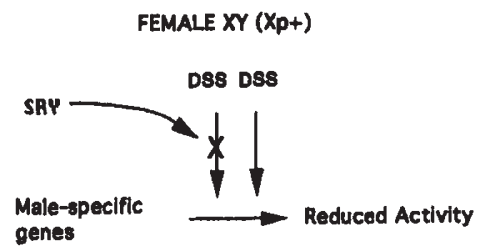


In some human familial cases of $S R Y$-negative sex reversal, complete masculinization (XX males) and partial masculinization ( $\mathrm{XX}$ true hermaphrodites) are observed. The spectrum of sex reversal often observed in these families can be simply explained by proposing that the $Z^{-}$mutation is leaky to different extents. The $S R Y$ gene is apparently normal in about 80 per cent of patients with complete $X Y$ sex reversal. These patients may harbour a different mutation in $Z$, termed $Z^{\mathrm{i}}$, such that $Z$ is insensitive to SRY action. As SRY is a DNA binding molecule, $Z^{i}$ mutations may be insensitive to SRY repression and thus may be considered to be constitutive mutations.

As described above, duplications of the DSS locus at $\mathrm{Xp} 21.3$ have been described in $\mathrm{XY}$ sex reversed females with either complete or partial testicular dysgenesis (Bardoni et al., 1994). However, deletions of the DSS locus do not affect testis determination in an $X Y$ individual. This apparent paradox can be explained if DSS functions as an inhibitor of testis development. SRY may repress or functionally antagonize the DSS gene product as described for hypothetical gene $Z$. The presence of two copies of $D S S$ may be sufficient to overcome the repression by $S R Y$ resulting in partial or complete inhibition of testis forming genes. In contrast, the absence of DSS in an XY individual will not affect testis determination as male-specific genes are constitutively expressed. If this hypothesis is correct some $\mathrm{XX}$ males may carry loss-of-function mutations at the DSS locus.

\section{Concluding remarks}

Many questions of mammalian sex determination still remain unresolved. SRY is the signal that determines the undifferentiated gonad to devleop as a testis, but how is this signal transduced to activate AMH expression? What controls the expression of $S R Y$ ? What is the next gene(s) in the cascade? What are the roles of $D A X-1$ and $S F-1$ in the pathway? What is the ligand for these two nuclear receptors? At the moment genetic arguments favour SRY functioning as a transcriptional repressor of an inhibitor of male development. The identification and functional analysis of other genes in the mammalian sex determining cascade will determine the validity of this hypothesis.

\section{References}

ABBAS, N., McElREAVEY, K. D., LECONIAT, M., VILAIN, E., JAUBERT, F., BERGER, R., NIHOUL-FEKETE, C., RAPPAPORT,
R. AND FELlous, M. 1993. Familial case of 46,XX male and $46, \mathrm{XX}$ true hermaphrodite associated with a paternal-derived $S R Y$-bearing $\mathrm{X}$ chromosome. C. r. Acad. Sci. Paris, 316, 375-383.

AFFARA, N. A., CHALMERS, I. J. AND FERGUSON-SMITH, A. 1993. Analysis of the $S R Y$ gene in 22 sex reversed $X Y$ females identifies four new point mutations in the conserved DNA-binding domain. Hum. Mol. Genet., 2, 785-789.

ARN, P., CHEN, H., TUCK-MUller, C. M., MANKINEN, C., WACHTEL, G., LI, S., SHEN, C.-C. AND WACHTEL, S. S. 1994. SRVX, a sex reversing locus in Xp21.2-p22.11. Hum. Genet., 93, 389-393.

BARDONI, B., Floridia, G., GUIOLI, S., PEVERALI, G., ANICHINı, C., CISTERNINO, M., CASALONE, R., DANESINO, C., FRACCARO, M., ZUFFARDI, O. AND CAMERINO, G. 1993. Functional disomy of Xp22-pter in three males carrying a portion of $\mathrm{Xp}$ translocated to Yq. Hum. Genet., 91, 333-338.

BARDONI, B., ZANARIA, F., GUIOLI, S., FLORIDIA, G., WORLEY, K. C., TONINI, G., FERRANTE, E., ChIUMEllo, G., MCCABE, E. R. B., FRACCARO, M., ZUFFARDI, O. AND CAMERINO, G. 1994. A dosage sensitive locus at chromosome $\mathrm{Xp} 21$ is involved in male to female sex reversal. Nat. Genet., 7, 497-501.

BEHLKE, M. A., BOGAN, J. S., BEER-ROMERO, P. AND PAGE, D. C. 1993. Evidence that SRY protein is encoded by a single exon on the human $\mathrm{Y}$ chromosome. Genomics, 17, 736-739.

BEHRINGER, R., CATE, R. L., FROELICK, G. J., PALMITER, R. AND BRINSTER, R. 1990. Abnormal sexual development in transgenic mice chronically expressing Müllerian inhibiting substance. Nature, 345, 167-170.

BERKOVITZ, G. D. 1992. Abnormalities of gonad determination and differentiation. Sem. Perinat., 16, 289-298.

BERNSTEIN, R., JENKINS, T., DAWSON, B., WAGNER, J., DEWALD, G., KOO, G. C. AND WACHTEL, S. S. 1980. Female phenotype and multiple abnormalities in sibs with a $\mathrm{Y}$ chromosome and partial $\mathrm{X}$ chromosome duplication: $\mathrm{H}-\mathrm{Y}$ antigen and $\mathrm{Xg}$ blood group findings. $J$. Med. Genet., 17, 291-300.

BERTA, P., HAWKINS, J. R., SINCLAIR, A. H., TAYLOR, A., GRIFFITHS, B., GOODFELLOW, P. N. AND FELLOUS, M. 1990. Genetic evidence equating SRY and the testis-determining factor. Nature, 348, 448-450.

CALl, K. M., GLASER, T., ITO, C. Y., BUCKLER, A. J., PELleTIER, J., HABER, D. A., ROSE, E. A., KRAL, A., YEGER, H., LEWIS, W. H., JONES, C. AND HOUSMAN, D. E. 1990. Isolation and characterization of a zinc finger polypeptide gene at the human chromosome 11 Wilms' tumor locus. Cell, 60, 509-520.

CAPEL, B., SWAIN, A., NICHOLIS, S., HACKER, A., WALTER, M., KOOPMAN, P., GOODFELLOW, P. AND LOVELL-BADGE, $R$. 1993. Circular transcripts of the testis-determining gene Sry in adult mouse testis, Cell, 73, 1019-1030.

CATTANACH, в. м. 1961. XXY mice. Genet. Res. 2, $156-158$.

CATtanach, B. M. 1962. XO mice. Genet. Res., 3, 487-490.

CHAPELlE, A. DE LA 1981. The etiology of maleness in XX 
men. Hum. Genet., 58, 105-116.

Chapelle, A. DE LA 1987. The Y-chromosomal and autosomal testis-determining genes. Development, 101, (Suppl.) 33-38.

ClÉPET, C., SCHAFER, A. J., SINClAIR, A. H., PALMER, M. S., LOVELl-BADGE, R. AND GOODFEllow, P. N. 1993. The human SRY transcript. Hum. Mol. Genet., 2, 2007-2012.

COOKE, C. T., MULCAHY, M. T., CULlity, G. J., WATSON, M. AND SPRAGUE, P. 1985. Campomelic dysplasia with sex reversal: morphological and cytogenetic studies of a case. Pathology, 17, 526-529.

COWARD, P., NAGAI, K., CHEN, D., HARRISON, T. D., NAGAMINE, C. M. AND YUN-FAI, C. L. 1994. Polymorphorism of a CAG trinucleotide repeat within $S r y$ correlates with B6. Y ${ }^{\text {DoM }}$ sex reversal. Nat. Genet., 6, 245-250.

DENNY, P., SWIFT, S., BRAND, N., DABHADE, N., BARTON, P. AND ASHWORTH, A. 1992. A conserved family of genes related to the testis determining gene, SRY. Nucl. Acids Res., 20, 2887.

DUBIN, R. A. AND OSTRER, H. 1994. Sry is a transcriptional activator. Mol. Endocrinol., 8, 1182-1192.

EICHER, E. M., WASHBURN, L. L., WHITNEY, J. B. AND MORROW, K. E. 1982. Mus poschiavinus Y chromosome in the C57/6J murine genome causes sex reversal. Science, 217, 535-537.

EICHER, E. M. 1994. Sex and trinucleotide repeats. Nat. Genet., 6, 221-223.

EICHER, E. M., WASHBURN, L. L., XU, X., DREDGE, D., SCHORK, N. J., ALBRECHT, K. H., TURTZO, L. C., HOPPE, P. C., PRINGle, J., SHOWN, E. P., LEE, B. K. AND PAGE, D. C. 1995. Autosomal genes involved in mammalian sex determination. J. Cell. Biochem., 19B, (Suppl.) Ab. B2003.

ESPINER, E. A., VEALE, A. M. O., SANDS, V. E. AND FITZGERALD, P. H. 1970. Familial syndrome of streak gonads and normal male karyotype in five phenotypic females. $N$. Engl. J. Med., 283, 6-11.

FECHNER, P. Y., MARCANTINO, S. M., OGATA, T., CROWLEY, M., Rosales, T. O., SMITH, K. D., GOODFEllow, P. N., MIGEON, C. J. AND BERKOVITZ, G. D. 1993. Report of a kindred with X-linked 46,XY partial gonadal dysgenesis. J. Clin. Endocrinol. Metab., 76, 1248-1253.

FERRARI, S., HARLEY, V. R., PONTIGGIA, A., GOODFELlOW, P. N., LOVELL-BADGE, R. AND BIANCHI, M. E. 1992. SRY like HMG1 recognises sharp angles in DNA. EMBO J., 11, 4497-4506.

FORD, C. E., JONES, K. W., POLANI, P. E., DE ALMEIDA, J. C. AND BRIGGS, J. H. 1959. A sex chromosome anomaly in a case of gonadal dysgenesis (Turner's syndrome). Lancet, i, 711-713.

FOSTER, J. W., DOMINGUEZ-STEGLICH, M. A., GUIOLI, S., KWOK, C., WELLER, P. A., STEVANOVIĆ, M., WEISSENBACH, J., MANSOUR, S., YOUNG, I. D., GOODFEllow, P. N., BROOK, J. D. AND SCHAFER, A. J. 1994. Campomelic dysplasia and autosomal sex reversal caused by mutations in an SRY-related gene. Nature, 372, 525-530.

GERMAN, J., SIMPSON, J. L., CHAGANTI, R. S. K., SUMMITT, R. L., REID, L. B. AND MERKATZ, 1. R. 1978. Genetically determined sex reversal in 46,XY humans. Science, 202 ,
53-56.

GIESE, K., COX, J. AND GROSSCHEDL, R. 1992. The HMG domain of the lymphoid enhancer factor 1 bends DNA and facilitates assembly of functional nucleoprotein structures. Cell, 69, 185-195.

gIESE, K., PAGel, J. AND GrosschedL, R. 1994. Distinct DNA-binding properties of the high mobility group domain of murine and human SRY sex-determining factors. Proc. Natl. Acad. Sci. U.S.A.., 91, 3368-3372.

GUBBAY, J., COLlignON, J., KOOPMAN, P., CAPEL, B., ECONOMOU, A., MÜNSTERBERG, A., VIVIAN, N., GOODFELLOW, P. AND LOVELL-BADGE, R. 1990. A gene mapping to the sex-determining region of the mouse $\mathrm{Y}$ chromosome is a member of a novel family of embryonically expressed genes. Nature, 346, 245-250.

HAQQ, C. M., KING, C-Y., UKIYAMA, E., FALSAFI, S., HAQQ, T. N., DONAHOE, P. K. AND WEISS, M. A. 1994. Molecular basis of mammalian sexual determination: activation of Müllerian inhibiting substance gene expression by SRY. Science, 266, 1494-1500.

HARLEY, V. R., JACKSON, D. I., HEXTALL, P. J., HAWKINS, J. R., BERKOVITZ, G. D., SOCKANATHAN, S., LOVELL-BADGE, R. AND GOODFELlOW, P. N. 1992. DNA-binding activity of recombinant SRY from normal males and $\mathrm{XY}$ females. Science, 255, 453-455.

HARLEY, V. R., LOVELL-BADGE, R. AND GOODFELLOW, P. N. 1994. Definition of a consensus DNA binding site for SRY. Nucl. Acids Res., 22, 1500-1501.

HAWKINS, J. R., TAYLOR, A., BERTA, P., LEVILLIERS, J., VAN DER AUWERA, B. AND GOODFEllow, P. N. 1992a. Mutational analysis of $S R Y$ : Nonsense and missense mutations in XY sex reversal. Hum. Genet., 88, 471-474.

HAWKINS, J. R., TAYLOR, A., GOODFELLOW, P. N., MIGEON, C. J., SMITH, K. D. AND BERKOVITZ, G. D. 1992b. Evidence for increased prevalence of SRY mutations in XY females with complete rather than partial gonadal dysgenesis. Am. J. Hum. Genet., 51, 979-984.

IKEDA, Y., LALA, D. S., LUO, X., KIM, E., MOISAN, M.-P. AND PARKER, K. L. 1993. Characterisation of the mouse FTZF1 gene, which encodes a key regulator of steroid hydroxylase gene expression. Mol. Endocrinol., 7, 852-860.

IKEDA, Y., SHEN, W.-H., INGRAHAM, H. A. AND PARKER, K. L. 1995. Developmental expression of mouse steroidogenic factor 1, an essential regulator of the steroid hydroxylases. Mol. Endocrinol. (in press).

IMBEAUD, S., CARRÉ-EUSÈBE, D., REY, R., BELVILle, C., JOSSO, N. AND PICARD, J.-Y. 1994. Molecular genetics of the persistent Müllerian duct syndrome: a study of 19 families. Hum. Mol. Genet., 3, 125-131.

JACOBS, P. A. AND STRONG, J. A. 1959. A case of human intersexuality having a possible $X X Y$ sex-determining mechanism. Nature, 183, 302-303.

JÄGER, R. J., ANVRET, M., HALL, K. AND SCHERER, G. 1990. A human XY female with a frame shift mutation in the candidate testis-determining gene SRY. Nature, 348, 452-454.

JAG̈ER, R. J., HARLEY, V. R., PFEIFFER, R. A., GOODFELLOW, P. N. AND SCHERER, G. 1992. A familial mutation in the 
testis determining gene $S R Y$ shared by both sexes. Hum. Genet., 90, 350-355.

JOST, A., VIGIER, B., PRÉPIN, J. AND PERCHELLETT, J. P. 1973. Studies on sex differentiation in mammals. Recent Prog. Horm. Res., 29, 1-41.

KRUGLYAK, L., DALY, M. J. AND LANDER, E. S. 1995. Rapid multipoint linkage analysis of recessive traits in nuclear families including homozygosity mapping. Am. J. Hum. Genet, 56, 519-527.

KUHNLE, U., SCHWARZ, H. P., LÖHRS, U., STENGEL-RUTHKOWSKI, S., CleVE, H. AND BRAUN, A. 1993. Familial true hermaphroditism: paternal and maternal transmission of true hermaphroditism $(46, \mathrm{XX})$ and $\mathrm{XX}$ maleness in the absence of Y-chromosome sequences. Hum. Genet., 92, 571-576.

LALA, D. S., RICE, D. A. AND PARKER, K. L. 1992. Steroidogenic factor 1 , a key regulator of steroidogenic enzyme expression is the mouse homolog of fushi tarazu-factor I. Mol. Endrocrinol., 6, 1249-1258.

LANDER, E. C. AND BOTSTEIN, D. 1987. Homozygosity mapping: a way to map human recessive traits with the DNA of inbred children. Science, 236, 1567-1570.

LAVORGNA, G., UEDA, H., CLOS, J. AND WU, C. 1991. FTZF1, a steroid hormone receptor-like protein implicated in the activation of fushi tarazu. Science, 252, 848-851.

LUO, X., IKEDA, Y. AND PARKER, K. L. 1994. A cell-specific nuclear receptor is essential for adrenal and gonadal development and sexual differentiation. Cell, 77, 481-490.

LYNCH, J. P., LALA, D. S., PEluSO, J. J., LUO, W., PARKER, K. L. AND WHITE, B.A. 1993. Steroidogenic factor 1, an orphan nuclear receptor regulates the expression of the rat aromatase gene in gonadal tissues. Mol. Endocrinol., 7, 776-786.

MANN, J. R., CORKERY, J. J., FISHER, H. J. W., CAMERON, A. H., MAYerova, A., WOLF, U., KeNNAUgh, A. A. AND WOOLLEY, V. 1983. The $\mathrm{X}$ linked recessive form of gonadal dysgenesis with a high level of gonadal germ cell tumours: clinical and genetic studies. J. Med. Genet., 20, 264-270.

MAY, K. M., GRIZAID, K. A. AND BLACKSTON, R. D. 1991. SeX reversal and multiple abnormalities due to abnormal segregation of $\mathrm{t}(\mathrm{X} ; 16)(\mathrm{p} 11.4 ; \mathrm{p} 13.3)$. Am. J. Hum. Genet., 49 (Suppl.) 19.

McElREAVEY, K., VIlaiN, E., ABbas, N., COSTA, J.-M., SOULEYREAU, N., KUCHERIA, K., BOUCEKKINE, C., THIBAUD, E., BRAUNER, R., FLAMANT, F. AND FELloUs, M. 1992. XY sex reversal associated with a deletion $5^{\prime}$ to the $S R Y$ "HMG box" in the testis-determining region. Proc. Natl. Acad. Sci. U.S.A., 89, 11016-11020.

MCELREAVEY, K., VILAIN, E., ABBAS, N., HERSKOWITZ, I. AND FELLOUS, M. 1993. A regulatory cascade hypothesis for mammalian sex determination: SRY represses a negative regulator of male development. Proc. Natl. Acad. Sci. USA, 90, 3368-3372.

MÜNSTERBERG, A. AND LOVELl-BADGE, R. 1991. Expression of the mouse anti-Müllerian hormone gene suggests a role in both male and female sexual differentiation. Development, 113, 613-624.
NARAHARA, K., KODAMA, Y., KIMURA, S. AND KIMOTO, H. 1979. Probable inverted tandem duplication of Xp in a 46,Xp + Y boy. Jap. Hum. Genet., 24, 105-110.

NASRIN, N., BUGGS, C., KONG, X. F., CARNAZZA, J., GOEBL, M. AND ALEXANDER-BRIDGES, M. 1991. DNA-binding properties of the product of the testis-determining gene and a related product. Nature, 354, 317-320.

NIELSEN, K. B. AND LANGKJAER, F. 1982. Inherited partial X chromosome duplication in a mentally retarded male. $J$. Med. Genet., 19, 222-224.

OGATA, T., HAWKINS, J. R., TAYLOR, A., MATSUO, N., HATA, J. AND GOODFEllow, P. N. 1992. Sex reversal in a child with a $46, X, Y p+$ karyotype: support for the existence of gene(s) located in distal $\mathrm{Xp}$, involved in testis formation. J. Med. Genet., 29, 226-230.

PaIlhouX, E., CRIBIU, E. P., ChafFaUX, S., DARre, R., FelLOUS, M. AND COTINOT, C. 1994. Molecular analysis of $60, \mathrm{XX}$ pseudohermaphrodite polled goats for the presence of $S R Y$ and $Z F Y$ genes. J. Reprod. Fert., 100, 491-496.

PAlmer, M. S., Sinclair, A. H., Berta, P., Ellis, N. A., GOODFEllow, P. N., ABBAS, N. E. AND FELlOUS, M. 1989. Genetic evidence that ZFY is not the testis-determining factor. Nature, 342, 937-939.

PALMER, S. J. AND BURGOYNE, P. s. 1991. The Mus musculus domesticus Tdy allele acts later than the Mus musculus musculus Tdy allele: a basis for XY sex-reversal in C57BL/6-Y ${ }^{\text {POS }}$ mice. Development, 113, 709-714.

PELletier, J., BRUENING, w., KASHTAN, C. E., MAUER, S. M., MANIVEL, J. C., STIEGEL, J. E., HOUGHTON, D. C., JUNIEN, C., HABIB, R., FOUSER, L., FINE, R. N., SILVERMAN, B. L., HABER, D. A. AND HOUSMAN, D. 1991. Germline mutations in the Wilms' tumor suppressor gene are associated with abnormal urogenital development in Denys-Drash syndrome. Cell, 67, 437-447.

RAO, P. N., KLINEPETER, K., STEWART, W., HAYWORTH, R., GRUBS, R. AND PETTENATI, M. J. 1994. Molecular cytogenetic analysis of a duplication $\mathrm{Xp}$ in a male: further delineation of a possible sex influencing region on the X chromosome. Hum. Genet., 94, 149-153.

RUSSELL, W. L., RUSSELL, L. B. AND GOWER, J. S. 1959. Exceptional inheritance of a sex-linked gene in the mouse explained on the basis that the X/O sex-chromosome constitution is female. Proc. Natl. Acad. Sci. U.S.A., 45, 554-560.

SCHERER, G., SCHEMPP, W., BACCICHETTI, C., LENZINI, E., BRICARELl, F. D., CARBONE, L. D. AND WOLF, U. 1989. Duplication of an Xp segment that includes the $Z F X$ locus causes sex inversion in man. Hum. Genet., 81, 291-294.

SHEN, W.-H., MOORE, C. C. D., IKEDA, Y., PARKER, K. L. AND INGRAHAM, H. A. 1994. Nuclear receptor steroidogenic factor 1 regulates the Müllerian inhibiting substance gene: a link to the sex determination cascade. Cell, 77, 651-661.

SINCLAIR, A. H., BERTA, P., PALMER, M. S., HAWKINS, J. R., GRIFFITHS, B. L., SMITH, M. J., FOSTER, J. W., FRISCHAUF, A.-M., LOVELL-BADGE, R. AND GOODFELlOW, P. N. 1990. A gene from the human sex-determining region

(c) The Genetical Society of Great Britain, Heredity, 75, 599-611. 
encodes a protein with homology to a conserved DNAbinding motif. Nature, 346, 240-245.

STERN, H. J., GARRITY, A. M., SAAL, H. M., WANGSA, D. AND DISTECHE, C. M. 1990. Duplication Xp21 and sex reversal: Insight into the mechanism of sex determination. Am. J. Hum. Genet., 47 (Suppl.), A41.

STERNBERG, W. H., BARCLAY, D. L. AND KLOEPFER, H. W. 1968. Familial XY gonadal dysgenesis. N. Eng. J. Med., 283, 6-11.

SU, H. AND LAU, Y.-F. C. 1993. Identification of the transcriptional unit, structural organisation and promoter sequence of the human sex-determining region Y (SRY) gene, using a reverse genetic approach. Am. J. Hum. Genet., 52, 24-38.

TAJIMA, T., NAKAE, J., SHINOHARA, N. AND FUJIEDA, K. 1994. A novel mutation localized in the $3^{\prime}$ non-HMG box region of the SRY gene in $46, \mathrm{XY}$ gonadal dysgenesis. Hum. Mol. Genet,., 3, 1187-1189.

VIGIER, B., WATRIN, F., MAGRE, S., TRAN, D. AND Josso, N. 1987. Purified bovine AMH induces a characteristic freemartin effect in fetal rat prospective ovaries exposed to it in vitro. Development, 100, 43-55.

VILAIN, E., FELloUs, M. AND McELREAVEY, K. 1992a. Characterisation and sequence of the $5^{\prime}$ flanking region of the human testis-determining factor, SRY. Methods Mol. Cell. Biol., 3, 128-134.

VILAIN, E., MCELREAVEY, K. D., JAUBERT, F., RAYMOND, J.-P., RICHAUD, F. AND FELlous, M. 1992b. Familial case with sequence variant in the testis-determining region associated with two sex phenotypes. Am. J. Hum. Genet., 50, 1008-1011.

WASHBURN, L. L. AND EICHER E. M. 1989. Normal testis determination in the mouse depends on genetic interaction of a locus on chromosome 17 and the Y chromosome. Genetics, 123, 173-179.

WRIGHT, E. M., SNOPEK, B. AND KOOPMAN, P. 1993. Seven new members of the Sox gene family expressed during mouse development. Nucl. Acids Res., 21, 744.

WOLF, U., SCHEMPP, w. AND SCHERER, G. 1992. Molecular biology of the human Y chromosome. Rev. Physiol. Biochem. Pharmacol., 121, 147-213.

ZANARIA, E., MUSCATELli, F., BARDONI, B., STROM, T. M., GUIOLI, S., WORLEY, K. A., LALLI, E., MOSER, C., WALKER, A. P., McCABE, E. R. B., Meltinger, T., MONACO, A. P., SASSONE-CORSI, P. AND CAMERINO, G. 1994. A novel and unusual member of the nuclear hormone receptor superfamily is responsible for X-linked adrenal hypoplasia congenita. Nature, 372, 635-641. 